\title{
Effect of Dietary Alfalfa Meal on Performance, Egg Quality, Egg Yolk Cholesterol and Hatchability Parameters of Quail Breeders
}

\author{
Osman Olgun $^{1 *}$, Alp Önder Yıldız \\ ${ }^{1 *}$ Department of Animal Science, Faculty of Agriculture, Selçuk University, 42075 Selçuklu/Konya, Turkey \\ ${ }^{2}$ Department of Crop and Animal Production, Fethiye Ali Sitkı Mefharet Koçman Vocational School, Muğla Sitkı Koçman University, 48300 \\ Fethiye/Muğla, Turkey
}

\section{A R T I C LE IN F O}

Article history:

Received 07 July 2014

Accepted 11 August 2014

Available online, ISSN: 2148-127X

Keywords:

Alfalfa meal

Cholesterol

Egg quality

Hatchability

Performance

Quails

\begin{tabular}{l}
${ }^{*}$ Corresponding Author: \\
\hline E-mail: oolgun@ selcuk.edu.tr
\end{tabular}

\begin{abstract}
A B S T R A C T
The aim of this study was to investigate the effects of different levels of alfalfa meal on performance, egg quality, egg yolk cholesterol and hatchability parameters of quail breeders. In this trial a total of 90 Japanese quail breeders (30 males, 60 females), 10 weeks old was distributed 5 experimental groups randomly. Each experimental group consisted of 6 replicates of 3 quails ( 1 males, 2 females) in each. During the 12 weeks experiment period, birds were fed with 5 dietary groups based on corn and soybean meal and containing 0 (control), 10, 20, 40 and $80 \mathrm{~g} / \mathrm{kg}$ alfalfa meal. Feed and water were offered ad-libitum throughout the experiment. The different dietary levels of alfalfa meal had no significant effect on body weight change, egg production, egg weight, egg mass, feed conversion ratio, egg shell breaking strength, egg yolk triglyceride, fertility, hatchability of fertile eggs or hatchability of eggs set. The feed intake was decreased with 10 or $20 \mathrm{~g} / \mathrm{kg}$ alfalfa meal levels in the diet. The eggshell weight was best in quails fed 20 $\mathrm{g} / \mathrm{kg}$ alfalfa meal, and the egg yolk cholesterol was the lowest in quails fed $40 \mathrm{~g} / \mathrm{kg}$ alfalfa meal. According to the results of this study the addition of $40 \mathrm{~g} / \mathrm{kg}$ alfalfa meal in laying quail diets decreased the egg yolk cholesterol levels without adverse effect on performance.
\end{abstract}

\section{Introduction}

Alfalfa is high in fiber content, and is most often added to poultry diets as a source of xanthophylls for pigmentation, or as a source of so-called unidentified growth factors (Leeson and Summers, 2005). Dehydrated alfalfa is usually used at a very low levels in poultry diets, due to its high crude fiber and low metabolic energy contents (Dansky, 1971); however, it is a rich source of vitamins, carotenoids (Sen et al., 1998) and saponins (Whitehead et al., 1981). Heywang (1950) reported that addition of alfalfa meal to the layer diets at the levels of $50,100,150$ and $200 \mathrm{~g} / \mathrm{kg}$ had no effect on feed intake (FI), but an addition of more than $5 \%$ decreased egg production (EP). Güçlü et al. (2004) indicated that addition of $90 \mathrm{~g} / \mathrm{kg}$ alfalfa meal into the laying quail diets had no adverse effect on performance and increased some of egg quality parameters. However, Mourao et al. (2006) reported that inclusion of alfalfa in diets of laying hens reduced performance expressed in terms of body weight and egg mass (EM). Tkacova et al. (2011) also reported that addition of high doses $(60 \mathrm{~g} / \mathrm{kg})$ of alfalfa had lower feed conversion in broiler.

Alfalfa also contains high levels (2 to $3 \%$ dry matter) of saponins, which have showed hypocholesterolemic, anticarcinogenic, anti-inflammatory, and antioxidant activity (Rao and Gurfinkel, 2000; Francis et al., 2002). Reshef et al. (1976) showed that parameters of lipid metabolism were not affected by alfalfa meal saponins, in addition to increased cholesterol biosynthesis in liver. Saponin is hypocholesterolemic due to formation of unabsorbable cholesterol-saponin complexes in the intestinal absorption site, thereby lower absorption of exogenous and endogenous cholesterol or increasing the fecal excretion of bile acids (Sim et al., 1984; Sidhu and Oakenfull, 1986; Jenkins and Atwal, 1994). Story and Kritchevsky (1976) founded that alfalfa meal is more effective than other sources of cellulose binding bile acids. Turk and Barnett (1972) and McNaughton (1978) reported that alfalfa meal in the diet decreased egg yolk cholesterol levels. Similarly, Güçlü et al. (2004) showed that the addition of $90 \mathrm{~g} / \mathrm{kg}$ alfalfa meal to laying quail diets decreased serum lipids and egg yolk cholesterol levels without adverse effect on performance. In contrast, some investigators reported that alfalfa meal had no effect on egg yolk cholesterol (Nakaue et al., 1980; Sim et al., 1984; Mourao et al., 2006).

As well as the limited number of studies on the effects 
of alfalfa meal in poultry, there is no study investigating the effects of alfalfa meal on reproductive performance of poultry. The influence of alfalfa meal on poultry breeder is also unclear. Therefore, this experiment was conducted to determine the effects of alfalfa meal on performance, egg quality, egg yolk cholesterol and hatchability parameters in quail breeders.

\section{Materials and Methods}

A total of 90 Japanese quail breeders (30 males, 60 females), 10 weeks old were distributed 5 experimental groups randomly. There were 6 replicates in each experiment group and in each replicates there were 3 (1 males, 2 females) birds. During the 12 weeks experiment period, birds were fed with 5 dietary groups based on corn and soybean meal and containing 0 (control), 10, 20, 40 and $80 \mathrm{~g} / \mathrm{kg}$ alfalfa meal. Experimental diets were balanced to meet or exceed the nutrient requirements for Japanese quail breeder (NRC, 1994) and formulated to be isocaloric and isonitrogenous with only the alfalfa meal levels in the diets differing (Table 1). Birds were housed in a breeder house equipped with 30 metal battery cages $(30 \times 45 \times 25 \mathrm{~cm})$. Feed and water were offered ad-libitum throughout the experiment (10-22 weeks). Light was provided for $16 \mathrm{~h} /$ day from 06:00 to 22:00 h throughout the experimental period. Quails were placed environmentally controlled room $\left(23-25^{\circ} \mathrm{C}\right)$.

Body weight was obtained by weighting quails at the beginning and at the end of the experimental period. Egg production was recorded daily. Feed intake and egg weight (EW) were recorded biweekly. Egg mass was calculated from collecting data of EP and EW at biweekly via the following formula:

$\mathrm{EM}=(\mathrm{EP} \times \mathrm{EW}) /$ Periods (days)
Feed conversion ratio (FCR, g feed/ g egg) was calculated via the following formula:

\section{$\mathrm{FCR}=\mathrm{FI}(\mathrm{g}$ of feed/quail/period $) / \mathrm{EM}$ (g of egg/quail/period)}

The eggshell quality characteristics (shell breaking strength and shell weight) were determined with all collected eggs produced at the last two days of the each of the two weeks periods during the whole experiment. Eggshell breaking strength was measured using a cantilever system by applying increased pressure to the broad pole of the shell using an instrument (Egg Force Reader, Orka Food Technology, Israel). Eggs were then broken, and eggshell, albumen, and yolk were separated and weighed. Eggshells were weighed using a $0.001 \mathrm{~g}$ precision scale. Eggshell weight was calculated via the following formula:

Eggshell weight $(\%$ of EW $)=[$ Eggshell weight $(g) / E W(g) \times 100]$

Twelve eggs from each group (2 eggs from each replicate) were collected at the end of the experiment to determine egg yolk total cholesterol and triglyceride levels. The egg yolk total cholesterol and triglyceride levels were determined by using the methods of Berrio and Hebert (1990), Hammad et al. (1996), with slight modifications by Eren and Uyanik (2007) and Boehringer Mannheim GmbH Biochemica (1989). The eggs were hard-boild for $15 \mathrm{~min}$, then the yolks were separated and $0.1 \mathrm{~g}$ samples of yolks were weighed accurately. Yolk lipids were extracted with isopropanol ( $4 \mathrm{ml} / 0.1$ of yolk), then vortex-mixed and centrifuged at $3000 \mathrm{rpm}$ for $5 \mathrm{~min}$. The yolk lipids determined in the samples filtered by spectrophotometer using a commercial kit (HUMAN Cholesterol liquicolor for cholesterol, HUMAN Triglucerides liquicolor ${ }^{\text {mono }}$ for triglyceride).

Table 1 Composition of experiment diets

\begin{tabular}{|c|c|c|c|c|c|}
\hline Ingredients & \multicolumn{5}{|c|}{ Alfalfa Meal, g/kg } \\
\hline $\mathrm{g} / \mathrm{kg}$ & Control & 10 & 20 & 40 & 80 \\
\hline Corn & 550.0 & 542.0 & 534.0 & 515.0 & 485.0 \\
\hline Soybean meal & 269.0 & 274.0 & 279.0 & 283.0 & 303.0 \\
\hline Sunflower meal & 70.0 & 60.0 & 50.0 & 40.0 & 00.0 \\
\hline Alfalfa meal & 0.0 & 10.0 & 20.0 & 40.0 & 80.0 \\
\hline Vegetable oil & 35.6 & 39.0 & 42.2 & 48.4 & 60.0 \\
\hline Limestone & 55.2 & 54.8 & 54.4 & 53.2 & 51.4 \\
\hline Dicalcium Phosphate & 13.0 & 13.0 & 13.1 & 13.1 & 13.2 \\
\hline Salt & 3.5 & 3.5 & 3.5 & 3.5 & 3.5 \\
\hline Premiks $^{1}$ & 2.5 & 2.5 & 2.5 & 2.5 & 2.5 \\
\hline DL-Methionine & 1.2 & 1.2 & 1.3 & 1.3 & 1.4 \\
\hline Total & 1000.0 & 1000.0 & 1000.0 & 1000.0 & 1000.0 \\
\hline \multicolumn{6}{|c|}{ Calculated nutrients } \\
\hline Metabolisable Energy, kcal/ kg ME & 2900 & 2902 & 2903 & 2901 & 2899 \\
\hline Crude Protein, g/kg & 200.1 & 200.0 & 200.0 & 200.3 & 200.2 \\
\hline Calcium, $\mathrm{g} / \mathrm{kg}$ & 25.00 & 25.02 & 25.06 & 25.00 & 24.97 \\
\hline Available $\mathrm{P}, \mathrm{g} / \mathrm{kg}$ & 3.51 & 3.50 & 3.51 & 3.50 & 3.48 \\
\hline Crude Cellulose, $\mathrm{g} / \mathrm{kg}$ & 38.38 & 39.58 & 40.78 & 44.00 & 48.83 \\
\hline Lysine, $\mathrm{g} / \mathrm{kg}$ & 10.53 & 10.52 & 10.51 & 10.44 & 10.39 \\
\hline Methionine, $\mathrm{g} / \mathrm{kg}$ & 4.55 & 4.51 & 4.57 & 4.49 & 4.42 \\
\hline Methionine + Cystine, $\mathrm{g} / \mathrm{kg}$ & 8.08 & 7.97 & 7.97 & 7.82 & 7.52 \\
\hline
\end{tabular}


Fertility and hatchability were determined by collecting eggs between the $11^{\text {th }}$ and the $12^{\text {th }}$ weeks of the experiment. Eggs were incubated at a temperature of $37.7^{\circ} \mathrm{C}$ with $65 \%$ relative humidity for $14 \mathrm{~d}$. They were then transferred at random to hatcher trays and were maintained at $37.2^{\circ} \mathrm{C}$ and $75 \%$ relative humidity until hatching. The numbers of hatched chicks were counted after $18 \mathrm{~d}$ of incubation then fertility, hatchability of fertile eggs and hatchability of set eggs in the treatment groups were also determined (Aygun et al., 2012).

Data were subjected to ANOVA by using One-Way in Minitab (2000). Duncan's multiple range tests were applied to separate means (Duncan, 1955). Statements of statistical significance were based on a probability of $\mathrm{P}<0.05$.

\section{Results and Discussion}

The body weight change (BWC), EP, EW, EM, FI and FCR are presented in the Table 2. In the present study, there were no significant differences in BWC, EP, EW, EM or FCR due to dietary alfalfa meal levels $(\mathrm{P}>0.05)$. There were significant reduction in the feed intake in the 10 or $20 \mathrm{~g} / \mathrm{kg}$ alfalfa meal including group $(\mathrm{P}<0.05)$; however, no significant differences were observed at higher dietary alfalfa meal levels (40 and $80 \mathrm{~g} / \mathrm{kg}$ ) when compared with the control group.

The egg breaking strength, eggshell weight, egg yolk cholesterol and triglyceride, fertility, hatchability of fertile eggs and hatchability of eggs set are presented in the Table 3. The levels of dietary alfalfa meal had no significant effect on egg breaking strength, egg yolk triglyceride content and characteristic of hatchability $(\mathrm{P}>0.05)$. Dietary levels of alfalfa meal had a significantly effect on eggshell weight and egg yolk cholesterol content. The lowest eggshell weight $(\mathrm{P}<0.05)$ and egg yolk cholesterol content $(\mathrm{P}<0.01)$ were obtained from 40 $\mathrm{g} / \mathrm{kg}$ alfalfa meal including diet.

According to the results of the present study, the dietary alfalfa meal had no significant effect on BWC, EP, EW, EM and FCR; but had a significant effect on FI $(\mathrm{P}<0.05)$. In earlier studies had shown that effects of alfalfa meal on performance could be different. Güçlü et al. (2004) reported that quail diets containing 30, 60 and $90 \mathrm{~g} / \mathrm{kg}$ alfalfa meal had no effects on performance parameters. Similar results have also been reported by Khajali et al. (2007). Sim et al. (1984) observed that the birds fed with saponin at $0.2 \mathrm{~g} / \mathrm{kg}$ or higher level in the diet were significantly decreased egg production and feed intake in laying hens. Mourao et al. (2006) showed that inclusion of alfalfa $(151 \mathrm{~g} / \mathrm{kg})$ in diets of laying hens decreased body weight at week 44, 48, and 52 and FI in the first 4 weeks of the experiment. In addition, they reported that the presence of alfalfa meal in the diet reduced $\mathrm{EP}, \mathrm{EW}$, and consequently the obtained EM.

Some of the previous studies showed that different levels of dietary alfalfa meal were not affected eggshell quality. Mourao et al. (2006) observed that alfalfa meal was not affected the eggshell quality such as the rate cracked eggs, shell thickness, or egg specific gravity. Also, Khajali et al. (2007) reported that alfalfa meal in the laying hen diets had no significant effects on eggshell thickness and eggshell breaking strength. These results can be said to be similar to the results of the present study. In the present study, the eggshell weight was significantly lower fed with the $40 \mathrm{~g} / \mathrm{kg}$ alfalfa meal in diets than 20 or $80 \mathrm{~g} / \mathrm{kg}$ alfalfa meal in diet; however, no significant differences were observed with alfalfa meal groups when compared with the control group. Otherwise, Güçlü et al. (2004) showed that 60 and $90 \mathrm{~g} / \mathrm{kg}$ alfalfa meal in the quail hens diet increased specific gravity of whole egg and eggshell thickness.

Table 2 Effects of different levels of alfalfa meal on performance of quail breeders

\begin{tabular}{|c|c|c|c|c|c|}
\hline \multirow[b]{3}{*}{ BWC, $\mathrm{g}$} & \multicolumn{5}{|c|}{ Alfalfa meal, $\mathrm{g} / \mathrm{kg}$} \\
\hline & Control & 10 & 20 & 40 & 80 \\
\hline & $7.06 \pm 6.23$ & $-7.22 \pm 2.36$ & $-2.47 \pm 4.62$ & $-12.56 \pm 8.92$ & $-0.50 \pm 3.72$ \\
\hline $\mathrm{EP}, \%$ & $90.51 \pm 0.95$ & $89.82 \pm 0.86$ & $89.57 \pm 0.36$ & $88.05 \pm 0.93$ & $90.70 \pm 0.34$ \\
\hline EW, g & $12.27 \pm 0.29$ & $12.41 \pm 0.19$ & $12.41 \pm 0.26$ & $12.58 \pm 0.21$ & $12.34 \pm 0.20$ \\
\hline $\mathrm{EM},(\mathrm{g} /$ quail/d) & $11.11 \pm 0.29$ & $11.15 \pm 0.17$ & $11.11 \pm 0.24$ & $11.08 \pm 0.24$ & $11.19 \pm 0.19$ \\
\hline FI, (g/quail/d) & $27.19 \pm 0.36^{\mathrm{a}}$ & $25.64 \pm 0.41^{\mathrm{bc}}$ & $25.24 \pm 0.42^{\mathrm{c}}$ & $26.11 \pm 0.44^{\mathrm{abc}}$ & $26.81 \pm 0.46^{\mathrm{ab}}$ \\
\hline FCR, ( $g$ feed/g egg) & $2.45 \pm 0.049$ & $2.30 \pm 0.049$ & $2.28 \pm 0.044$ & $2.36 \pm 0.077$ & $2.40 \pm 0.062$ \\
\hline
\end{tabular}

${ }^{*}$ Different superscripts ${ }^{\mathrm{a}, \mathrm{b}, \mathrm{c}}$ indicate significant differences $(\mathrm{P}<0.05)$ according to the dietary alfalfa meal levels.

Table 3 Effects of different levels of alfalfa meal on egg quality and hatchability of quail breeders

\begin{tabular}{|c|c|c|c|c|c|}
\hline \multirow[b]{3}{*}{ Eggshell Quality } & \multicolumn{5}{|c|}{ Alfalfa meal, $\mathrm{g} / \mathrm{kg}$} \\
\hline & Control & 10 & 20 & 40 & 80 \\
\hline & & & & & \\
\hline Egg breaking strength, $\mathrm{kg}$ & $1.61 \pm 0.06$ & $1.66 \pm 0.04$ & $1.71 \pm 0.03$ & $1.62 \pm 0.04$ & $1.59 \pm 0.06$ \\
\hline Eggshell weight, $\%$ & $8.42 \pm 0.13^{\mathrm{ab}}$ & $8.35 \pm 0.07^{\mathrm{ab}}$ & $8.55 \pm 0.08^{\mathrm{a}}$ & $8.14 \pm 0.09^{\mathrm{b}}$ & $8.52 \pm 0.09^{\mathrm{a}}$ \\
\hline Egg yolk & & & & & \\
\hline Cholesterol, mg/dl & $147.1 \pm 1.22^{\mathrm{A}}$ & $145.8 \pm 2.00^{\mathrm{A}}$ & $144.7 \pm 1.26^{\mathrm{AB}}$ & $139.9 \pm 0.77^{\mathrm{B}}$ & $142.6 \pm 1.12^{\mathrm{AB}}$ \\
\hline Triglyceride, $\mathrm{mg} / \mathrm{dl}$ & $109.1 \pm 1.77$ & $108.0 \pm 0.76$ & $108.0 \pm 1.13$ & $109.3 \pm 2.29$ & $110.9 \pm 2.11$ \\
\hline Hatchability & & & & & \\
\hline Fertility, $\%$ & $97.11 \pm 1.94$ & $93.89 \pm 3.08$ & $93.33 \pm 5.44$ & $92.45 \pm 2.85$ & $89.58 \pm 6.10$ \\
\hline Hatchability of fertile eggs, $\%$ & $78.29 \pm 5.39$ & $77.74 \pm 6.08$ & $84.98 \pm 4.03$ & $82.50 \pm 4.00$ & $81.35 \pm 6.03$ \\
\hline Hatchability of eggs set , $\%$ & $75.86 \pm 4.93$ & $73.09 \pm 6.48$ & $78.98 \pm 5.50$ & $76.60 \pm 5.39$ & $71.68 \pm 4.85$ \\
\hline
\end{tabular}

*Different superscripts ${ }^{\mathrm{A}, \mathrm{B}}$ indicate significant differences $(\mathrm{P}<0.01)$ according to the dietary alfalfa meal levels.

*Different superscripts ${ }^{\mathrm{a}, \mathrm{b}}$ indicate significant differences $(\mathrm{P}<0.05)$ according to the dietary alfalfa meal levels. 
The present study, the egg yolk cholesterol was significantly lower in the $40 \mathrm{~g} / \mathrm{kg}$ alfalfa meal including diet when compared with control or $10 \mathrm{~g} / \mathrm{kg}$ alfalfa meal including groups. McNaughton (1978) observed that the alfalfa meal in the laying hens decreased the egg yolk cholesterol. Similarly, Güçlü et al. (2004) demonstrated that a significant decrease in the egg yolk cholesterol by feeding alfalfa meal in quails. Similar results have also been reported by Turk and Barnett (1972) and Khajali et al. (2007). On the other hand, these results do not agree with some of investigators who observed that alfalfa meal had no effect on egg yolk cholesterol (Mourao et al., 2006) or saponin (Sim et al., 1984) in laying hens.

\section{Conclusion}

Inclusion of 10 or $20 \mathrm{~g} / \mathrm{kg}$ alfalfa meal levels in the diets of quail breeders reduced FI, but it is no effect on others performance parameters. Forty $\mathrm{g} / \mathrm{kg}$ of alfalfa meal in quail breeder diets decreased egg yolk cholesterol. Addition of alfalfa meal to quail breeder diets slightly decreased fertility; however, it is slightly increased hatchability of fertile eggs.

\section{References}

Aygun A, Sert D, Copur G. 2012. Effects of propolis on eggshell microbial activity, hatchability, and chick performance in Japanese quail (Coturnix coturnix japonica) eggs. Poult Sci., 91:1018-1025.

Berrio LF, Hebert JA. 1990. The effect of adding cholesterol to laying hen diets as powder or predissolved in fat. Poult Sci., 69:972-976.

Boehringer Mannheim GmbH Biochemica. 1989. Methods of biochemical analysis and food analysis. Mannheim Germany: 26-28.

Dansky LM. 1971. A role for alfalfa in high efficiency broiler rations. Poult Sci., 50:1569-1574.

Duncan DB. 1955. Multiple Range and Multiple F tests. Biometrics 11: 1-42.

Eren M, Uyanik F. 2007. Influence of dietary boron supplementation on some serum metabolites and egg-yolk cholesterol in laying hens. Acta Vet Hung., 55:29-39.

Francis GZ, Kerem H, Makkar P, Becker K. 2002. The biological action of saponins in animal systems: A review. Br J Nutr., 88:587-605.

Güçlü B, İşcan KM, Uyanık F, Eren M, Ağca AC. 2004. Effect of alfalfa meal in diets of laying quails on performance, egg quality and some serum parameters. Arch Anim Nutr., 58:255-263.

Hammad SM, Siegel HS, Marks HL. 1996. Dietary cholesterol effects on plasma and yolk cholesterol fractions in selected lines of Japanese quail. Poult Sci., 75:933-942.

Heywang BW. 1950. High levels of alfalfa meal in diets for chickens. Poult Sci., 29:804-811.
Jenkins KJ, Atwal AS. 1994. Effects of dietary saponins on fecal bile acids and neutral sterols, and availability of vitamins A and $E$ in the chick. J Nutr Biochem. 5:134-135.

Khajali F, Eshraghi M, Zamani F, Fathi E. 2007. Supplementation of exogenous enzymes to laying hen diets containing alfalfa: Influence upon performance and egg yolk cholesterol and pigmentation. Proc. $16^{\text {th }}$ Euro. Symp. Poult. Nutr. p:713-715. France.

Leeson S, Summers JD. 2005. Commercial poultry production. 3rd Edition. University Books, Guelph, Ontario.

McNaughton JL. 1978. Effect of dietary fiber on egg yolk, liver, and plasma cholesterol concentrations of the laying hen. $\mathbf{J}$ Nutr., 108:1842-1848.

Minitab, 2000. Minitab reference manual (release 13.0). Minitab Inc. State Coll., PA.

Mourao JL, Ponte PIP, Prates JAM, Centeno MSJ, Ferreira LMA, Soares MAC, Fontes CMGA. 2006. Use of $\beta$ glucanases and $\beta-1,4$-xylanases to supplement diets containing alfalfa and rye for laying hens: Effects on bird performance and egg quality. J Appl Poult Res., 15:256-265

Nakaue HS, Lowry RR, Cheeke PR, ArsCott GH. 1980. The effect of dietary alfalfa of varying saponin content on egg cholesterol level and layer performance. Poult Sci., 59:27442748.

National Research Council (NRC), 1994. Nutrient requirement of poultry. 9th rev. ed. National Academy Press, Washington DC.

Rao AV, Gurfinkel DM. 2000. The bioactivity of saponins: Triterpenoid and steroidal glycosides, Drug Metabol Drug Interact., 17:211-235.

Reshef G, Gestetner B, Birk Y, Bondi A. 1976. Effect of alfalfa saponins on the growth and some aspects of lipid metabolism of mice and quails. J Sci Food Agricul., 27:6372.

Sen S, Makkar HPS, Becker K. 1998. Alfalfa saponins and their implications in animal nutrition. J Agric Food Chem., 46:131-140.

Sidhu GS, Oakenfull DG. 1986. A mechanism for the hypocholesterolaemic activity of saponins. $\mathrm{Br} \mathrm{J}$ Nutr., 55:643-649.

Sim JS, Kitts WD, Bragg DB. 1984. Effect of dietary saponin on egg cholesterol level and laying hen performance. Can J Anim Sci., 64:977-984.

Story JA, Kritchevsky D. 1976. Comparison of the binding of various bile acids and bile salts in vitro by several types of fiber. J Nutr., 106:1292-1294.

Tkacova J, Angelovicova M, Mrazova L, Kliment M, Kral M. 2011. Effect of different proportion of lucerne meal in broiler chickens. Anim Sci Biotech., 44:141-144.

Turk DE, Barnett BD. 1972. Diet and egg cholesterol. Poult Sci., 51:1881.

Whitehead CC, McNab JM, Griffin HD. 1981. The effects of low dietary concentrations of saponin on liver lipid accumulation and performance in laying hens. Poult Sci., 22:281-288. 